\title{
Physical and Facilities Factors Influencing Tourist Distribution in Bantul Regency, Special Region of Yogyakarta
}

\author{
Akhmad Shidiq Darajat ${ }^{1}$, M. H. Dewi Susilowati ${ }^{2 *}$ \\ ${ }^{1}$ Department of Geography, Faculty of Mathematics and Natural Sciences, Universitas Indonesia \\ ${ }^{2}$ Department of Geography, Faculty of Mathematics and Natural Sciences, Universitas Indonesia \\ email: akhmadshidiq@gmail.com; *Corresponding author's email: mhdsusilowati@gmail.com
}

\begin{abstract}
Bantul Regency is one of favorite of tourism in Special Region of Yogyakarta. Bantul's landscape are very different, more than half area is below $50 \mathrm{~m}$ and around 70 percent area consist agricultural lanscapes. Bantul Regency have many primary, secondary and conditional facilities, along accessibility. Variety of facilities cause differences number tourist. The objective of reseach was to analyze physical and facilities factors influencing tourist distribution. The method used are spatial and statistical analysis (chi-square). Based on spatial analysis shows: (1) physical factors are different, indicating flat on souther and plain on western; (2) the most facilities are placed at southern, especially Parangtritis Beach; (a) primary facilities covering most natural attractions in southern coastal areas and cultures in westhern with plain terrain; (b) the highest of secondary and conditional facilities are located at Parangtritis Beach;(d) highest accessibility is at Parangtritis Beach; (3) most tourist are placed at southern, especially Parangtritis Beach. Based on statistical analysis shows: (1) the influence of physical factors on distribution of number tourists is not significant at the significance level $(\alpha)=0.05$; (2) Correlation between number tourist and facilities is significant and indicate the value of correlation is 0.959 .
\end{abstract}

Keywords: terrain, facilities, tourist distribution.

\section{Introduction}

Tourism has become one of the industry sectors that provide a great income for a region or country. Tourism was used by various countries for economic development [1]. Tourism has grown rapidly to become one of the world's foremost economic phenomena [4]. At this time the tourism industry is progressing rapidly, it should take full advantage of all existing potentials, and thus be expected to generate development in the region [10]. Tourism in Indonesia is an important economic sector in Indonesia. Natural and cultural resources is an important component of tourism in Indonesia. The tourism sector has become the main source of income for countries contributing strongly to economies, generating markets for a wide variety of goods and services both directly and indirectly related to tourism [2].

Indonesia has a tropical climate, 17.508 island and the length of coastline are $99.000 \mathrm{kms}$ and have interesting attractions for domestic and foreign tourists. The development of tourism can not be separated from the increasing number of tourist destinations and the development of the destination. Tourist destination has certain requirements in order to grow that has a diversity of attractions, availability of accessibility and facilities as well as the convenience of tourists [7]. Tourism continues to grow and not be separated from the many tourist destinations.

The success of a tourist destination in the world market is influenced by the attractiveness and competitiveness of their [5]. Indonesia has many interesting tourist destinations to visit. One of the favorite tourist destinations in Yogyakarta is Bantul regency. Bantul Regency has a beach tour located in the south and visited by many tourists. Bantul Regency has variety of tours that are nature tourism and cultural tourism. Nature tourism contained in Bantul Regency consists of coastal tourism, cave tours and others. As for cultural tourism consists of various museums or historic buildings.

The main component in tourism there are three, among other tourist attractions, tourist facilities and accessibility [3]. These components are interconnected and support for the development of tourism object. The tourists became the main parameters in the success of tourism. In addition, tourist facilities and infrastructure can also support the success of a tourism object. Tourist objects will be said to be interesting if much visited by tourists.

* Corresponding author: mhdsusilowati@gmail.com 
Various efforts have been made to identify the determinant attributes or indicators of destination [9]. Determinants for measures of destination attractiveness have classified tourism products at the destination into five main components. They include natural factors, social factors, historical factor, recreation and shopping facilities, and infrastructure and food and shelter [6].

Bantul Regency is mostly in the physical condition of lowland especially in the south. In addition, there are hilly areas that are in the west. Physical condition that varies there are many locations of natural and cultural tourism. The purpose of this study is to analyze the relationship beetwen physical factors of the number of tourists and tourist facilities to the number of tourists at several locations of attractions in Bantul Regency.

\section{Methodology}

\section{A. Research Area}

Distribution of Tourism Object in Bantul Regency, Special Region of Yogyakarta can be seen in figure 1 . Tourism object to be researched are 14 locations of tourism object in bantul regency. The tourism object consists of nature and cultural tourism. Tourism object in dbantul regency include Parangtritis Beach, Samas Beach, Kwaru Beach, Goa Cemara Beach, Selarong Cave, Cerme Cave, Imogiri tomb, Pine Forest mangunan, orchards Mangunan, Museum of Javanese farmers Indonesia, Culture House Tembi Museum, Pleret Archaeological Museum, Museum of the Sand Dunes, and Soeharto Museum.

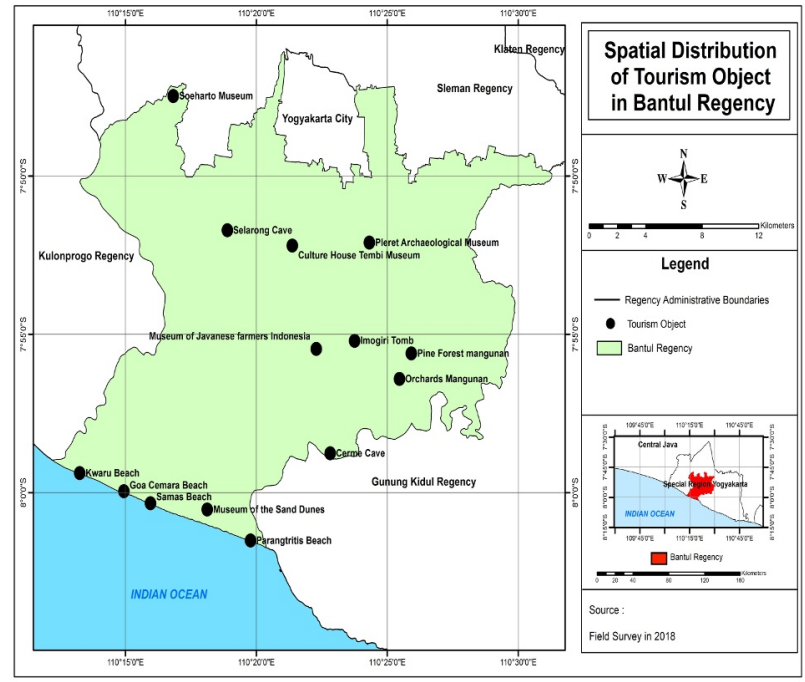

Figure 1. Distribution of Tourism Object in Bantul Regency

\section{B. Research framework}

Bantul Regency has a variety of tourism including natural and cultural tourism. Bantul regency has a varied physical condition on topography from lowland to hilly. In the physical condition there are several locations that serve as a tourim object such as natural attractions such as beaches. Each tourism object in Bantul Regency has different facilities and accessibility with each other so that the number of tourists varies as well. Research Framework can be seen in figure 2 .

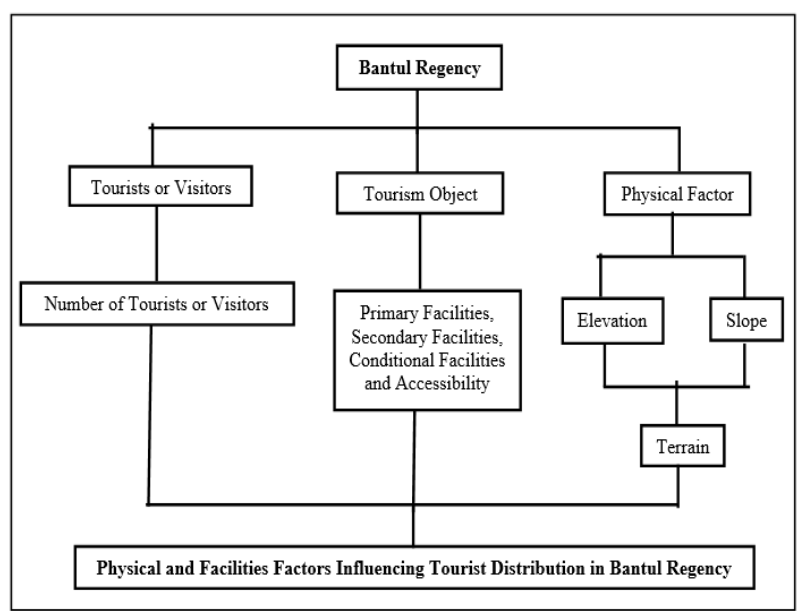

Figure 2. Research Framework

\section{Data collection}

Data collected in this study consisted of data included : (1) the number of tourist in 2016 every location of tourism object in Bantul Regency; (2) primary facilities (site and event attraction); (3) secondary facilities (restaurants, hotels, souvenir shops); (4) conditional facilities (places of worship, parking and toilets); (5) accessibility (road network and public transportation); (6) and physical condition (altitude, slope, and terrain).

\section{Data processing}

Data processing includes: (1) classification of tourist data, fasilities data classification (primary, secondary, conditional); (2) the spatial and tabular data processing technology with Geographic Information System (GIS); (3) quantitative data processed by SPSS (Statistical Product and Service Solutions).

\section{E. Data analysis}

Analysis of data used is spatial analysis with a map to show the distribution of tourism object, facilities of tourism and physical condition in Bantul Regency. Statistical analysis (chi-square) was used to determine correlation between the number of tourist and physical (terrain) in Bantul Regency.

\section{Results and Discussion}

\section{A. Number of tourists on tourism object}

The number of tourists on the tourism object in Bantul Regency varies and different between tourist objects. The number of tourists is mostly in the south of Bantul regency or in coastal areas. Based on data from the tourism office in 2016, the number of tourists on 
each tourism object has increased from the previous year. Tourism object that has the highest number of tourists is Parangtritis beach. Meanwhile, the tourism object with the lowest number of tourists on the type of cultural tourism is a museum ancient pleret. Variation of tourist on tourism object Bantul Regency can seen in figure 3 .

The number of tourists in each tourism object in Bantul regency in 2016 is divided into 3 classes with the following limits:

1. Low class with number of tourist $<300.000$, there are tourism object such as Kwaru Beach, Goa Cemara Beach, Selarong Cave, Cerme Cave, Imogiri tomb, Museum of Javanese farmers Indonesia, Culture House Tembi Museum, Pleret Archaeological Museum, Samas Beach, Soeharto Museum and Museum of the Sand Dunes.

2. Medium class with the number of tourists from 300,000 to 600.000 , tourism object that include the medium class is Pine Forest mangunan and orchard mangunan.

3. High class with more than 600,000 tourists, tourism object that include the high class is Parangtritis Beach.

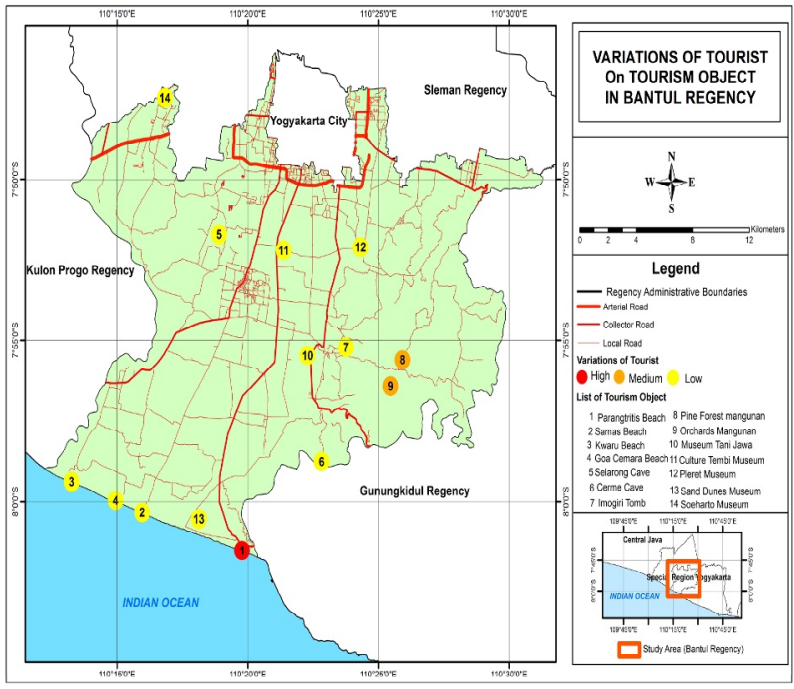

Figure 3. map variation of tourist on tourism object in Bantul Regency

\section{B. Facilities of Tourism Object in Bantul Regency}

\section{Primary Facilities}

Primary facility is divided into two namely site attraction and event attraction. Tourism object in Bantul Regency is basically dominated by the main attraction types of natural attractions such as beach tourism and cave tourism. In addition, other tourism object such as cultural tourism is also still awake and attracted tourists. Most of tourism object has diverse and different attractions, especially on nature tourism in Bantul regency.
One of the natural tourism object that has many diverse attractions is Parangtritis beach. Other natural attractions also have a diverse attraction of the cave mire, cave selarong, fruit gardens mangunan, and beach cypress. Bantul Regency also has a unique and diverse cultural attractions. Each of these cultural attractions has different attractions. One of the cultural tourism found in Bantul Regency is Museum of Javanese farmer Indonesia. The Indonesian Javanese Farmer Museum is a museum that stores the tools used for farming. This museum also shows the culture of farmers to tourists with events or events such as memedi sawah festivals.

\section{Secondary Facilities}

Secondary facilities contained in tourism object such as lodging, restaurants and souvenir shops. Each tourism object in Bantul Regency has a difference in the number of secondary facilities available. Secondary facilities function in supporting the tourism object so that tourists can enjoy better tours. Parangtritis beach as many as 18 hotels.

\section{Conditional Facilities}

Conditional facilities on tourism object such as parking lots, places of worship and toilets. Conditional facility is used or functioned to facilitate the tourists to the tourism activities undertaken so as to attract tourists. Each tourism object has a difference in the number of conditional facilities provided for tourism object. Some tourism object in Bantul regency has complete facility, especially Parangtritis beach. There are also tourism object have facilities that are less complete as in the Archaeological Pleret Museum.

\section{Accessibility}

According Burton (1995), accessibility can not be separated by the availability of transport systems: (1) Transportation of transport such as cars, buses, trains, aircraft; (2) The road network such as roads, railways, air lines. Accessibility is a means or infrastructure that is important in supporting tourism in a region. Accessibility of tourism object can be seen from the road network and transportation. The road network is viewed based on road functions such as arterial roads, collector roads, and local roads. Transportation used to reach the location of tourism object in Bantul Regency is still low due to the availability of public transport only exist for some locations of tourism object.

\section{Physical Condition in Bantul Regency}

Physical condition of Bantul Regency is in the form of elevation and slope obtained from the processing of image data or DEM (Digital Elevation Model) of 30 meters. Bantul Regency has a height between 0-500 m. Mostly dominated by altitude from 0-100 m. Bantul Regency has slopes vary from 0 to more than $40 \%$. Most of the slopes of Bantul Regency are at 0 to $2 \%$. Elevation data and slope data will be overlay to create terrain of Bantul Regency. The classification of elevation, slope and terrain according to the 
classification by Van Zuidam in 1985 [8]. Terrain classification can be seen in table 1 .

Table 1. Terrain classification

\begin{tabular}{|l|c|c|}
\hline \multicolumn{1}{|c|}{ Terrain } & Slope (\%) & Elevation $(\mathrm{m})$ \\
\hline Flat & $0-2$ & $<7$ \\
\hline $\begin{array}{l}\text { Flat to } \\
\text { undulating }\end{array}$ & $3-7$ & $7-25$ \\
\hline Undulating & $8-13$ & $25-75$ \\
\hline $\begin{array}{l}\text { Undulating to } \\
\text { hilly }\end{array}$ & $14-20$ & $75-200$ \\
\hline Hilly & $21-55$ & $200-500$ \\
\hline $\begin{array}{l}\text { steep } \\
\text { mountains }\end{array}$ & $>55$ & $>500$ \\
\hline
\end{tabular}

Based on the terrain classification, Bantul Regency consists of flat, undulating and hilly terrain. Bantul Regency in the southern region is along the relatively flat coast. Along the beach in the south there are several locations that serve as tourim object. Famous tourism object along the southern coast of Bantul is a tourist beach Parangtritis. Bantul Regency in the western region is a hilly area with $40 \%$ slope and an altitude between 200-500 m. Hilly areas are also there are some locations that serve as a tourism object. Physical Condition in Bantul Regency can be seen in figure 4 . One of the tourism object that is on the hilly terrain is the pine forest tour mangunan. Tourists who come to the location of pine forest attractions mangunan experience a little difficulty in reaching the tour because it is located in a relatively hilly areas.

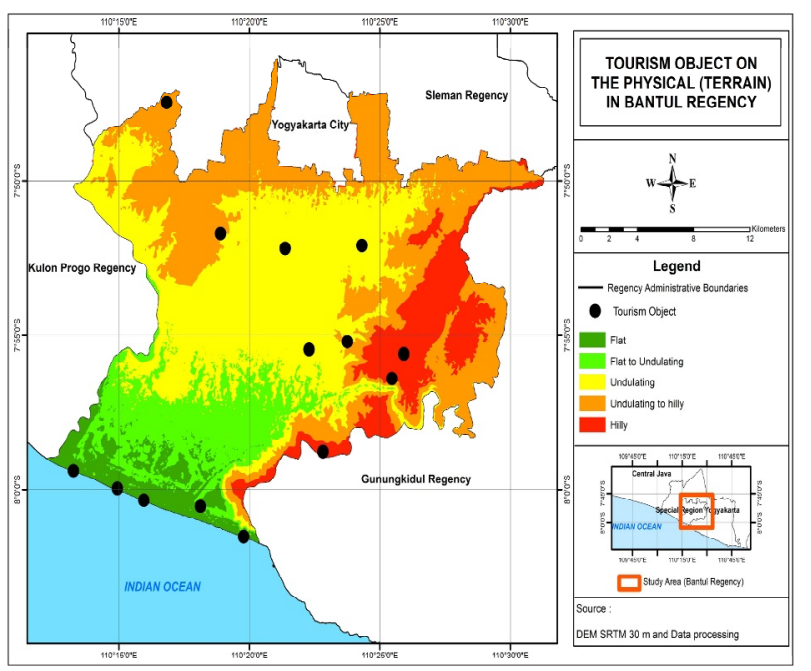

Figure 4. Map distribution of tourism object on the physical (terrain) in Bantul Regency

\section{The relationship between physical factors and number of tourists}

Based on spatial analysis indicates that the relatively flat physical condition in southern Bantul, there are many tourist objects visited by tourists compared with tourist objects on hilly physical conditions. The largest number of tourists are on the beach tour Parangtritis. Parangtritis beach tourism is a relatively flat beach along the coast. Accessibility is also easy so tourists continue to increase. While the number of tourists in hilly areas is still a little because of the difficult to reach attractions and rather steep terrain.

The result statistical of test Chi Sqare between physical factors and number of tourists can be seen in table 2. The level of significance $(\alpha)$ used is 0,05 . The chi square statistic shows the correlation value or value Asymp.Sig is 0,114. Asymp.Sig value is $0,114>0,05$ (level of significance). This means that showed there was no significant relationship between physical factors and distribution number of tourists.

Table 2. Result Chi Square Test

\begin{tabular}{|l|c|c|c|}
\hline & Value & df & $\begin{array}{c}\text { Asymp. Sig. } \\
\text { (2-sided) }\end{array}$ \\
\hline Pearson Chi- & $10.267^{\mathrm{a}}$ & 6 & .114 \\
Square & 9.544 & 6 & .145 \\
Likelihood Ratio \\
$\begin{array}{l}\text { Linear-by-Linear } \\
\text { Association } \\
\text { N of Valid Cases }\end{array}$ & .026 & 1 & .872 \\
\hline
\end{tabular}

\section{E. The relationship between facilities and number of tourists}

Based on spatial analysis indicates that the most number of visitors are in tourism object that has complete facilities (primary, secondary and conditional facilities). Tourism object that has complete facilities is Parangtritis beach. Other tourism object also have complete facilities such as cave selarong tour, samas beach, and pine forest. Tourism object whose facilities are less complete are dominated by cultural attractions such as sand dune museum, archaeological pleret, and others. Tourism object with little or no complete facilities less desirable by tourists. Based on statistical analysis show that the correlation between the number of tourist and facilities is significant and indicate the value of correlation is 0.959 . Result of Statistical between facilities and number of tourists can be seen in table 3 . 


\begin{tabular}{|ll|r|r|}
\hline & & Tourist & \multicolumn{1}{|c|}{ Fasilities } \\
\hline Tourist & Pearson & 1 & $.959^{* *}$ \\
& Correlation & & \\
& Sig. (2-tailed) & & .000 \\
& $\mathrm{~N}$ & 14 & 14 \\
\hline Facilities & Pearson & $.959^{* *}$ & 1 \\
& Correlation & & \\
& Sig. (2-tailed) & .000 & 14 \\
& $\mathrm{~N}$ & 14 &
\end{tabular}

Table 3. Result Statistical Test

\section{Conclusions}

Variation of tourist based on the spatial showed the most tourist are placed at southern, especially Parangtritis Beach. The most facilities are placed at southern, especially Parangtritis Beach. Primary facilities covering most natural attractions in southern coastal areas and cultures in westhern. Highest of secondary and conditional facilities are located at Parangtritis Beach. Highest accessibility is at Parangtritis Beach. Physical factors are different, indicating flat on souther and hilly on western. Influence of physical factors on distribution of number tourists is not significant at the significance level $(\alpha)=0.05$. Correlation between number tourist and facilities is significant and indicate the value of correlation is 0.959 .

Development of tourism facilities needs to be done to encourage economic activities, increase local revenue and take advantage of the best possible environment. Tourism activities can have a negative impact with the planning that does not pay attention to the carrying capacity of the environment and the lack of awareness and education of the community and tourists towards environmental preservation. The tourism based development process in this paper shows that an area can develop well accompanied by improving facilities, accessibility and human resources in managing tourism and to reduce carbon or create a low-carbon community environmentally friendly transportation means in transporting tourists who come to a tourist attraction. This paper can be used to analyze the number of tourists who come and the facilities provided so that it can be pursued for the provision of low-carbon or environmentally friendly transportation.

\section{References}

[1] Awang, K, W., Hassan, W.M. \& Zahari, M.S (2009). Tourism Development; A Geographical Perspective. Asian Social Science 5 (5), 67-76.

[2] Bernini, C \& Cracolici, M F. (2015). Demographic change, tourism expenditure and life cycle behaviour. Journal Tourism Management 47, 191205.

[3] Burton, R. (1995). Travel Geography. London: Pitman Publishing.

[4] Deng, J., King, B., \& Bauer, T. (2002). Evaluating Natural Attraction for Tourism. Annals of Tourism Research 29 (2), 422-438.

[5] Enright, M. J., \& Newton, J. (2004). Tourism destination competitiveness: a quantitative approach. Tourism Management 25 (2004), 777788.

[6] Gearing, C.E., Swart. W.W., \& Var, T. (1974). Establishing a measure of touristic attractiveness. Journal of Travel Research 12 (4), 1-8.

[7] Mill, R. C. (2000). Tourism, The International Business. Jakarta: Penerbit Raja Grafindo.

[8] Van Zuidam, R. A. (1985). Aerial Photo Interpretation in Terrain Analysis and Geomorphologic Mapping. Smith Publisher, The Hague, ITC.

[9] Var, T., Beck, R.A., \& Loftus, P. (1977). Determination of Touristic Attractiveness of the Touristic Areas in British Columbia. Journal of Travel Research 15 (3), 23-29.

[10] Zaidan, E. (2016). The Impact of Culture Distance on Local Residence on Local Residents perception of Tourism Development: The Case of Dubai in UAE. Journal of Tourism, vol 64 (1) 109-126 